\title{
Applications of Customer Focused E-Learning
}

\author{
Corinne Montandon and Marianne Zentriegen \\ University of Bern, Bern, Switzerland
}

\section{corinne.montandon@iwi.unibe.ch marianne.zentriegen@iwi.unibe.ch}

\begin{abstract}
This paper provides information on customer focused e- learning (CFEL). It is an overview on the application area of CFEL and the potential of its business applications. Training of customers holds some undiscovered potential. CFEL is a new concept and little technical literature is available yet. In the majority of cases a differentiation is made between the category groups e-learning as business segment (private training) and e- learning as marketing instrument (educommerce). In this paper product training is considered as a third type of CFEL. For the illustration of possible applications of CFEL, numerous practical examples are given. This paper then goes on to develop these ideas in a practical way through case studies of the e-learning provision of three Swiss companies. This paper refers solely to corporate e-learning, whereas employee and supplier training is not considered. Especially in the sectors of computer science, financial services, staffing and employment service, and health care, the odds for an early breakthrough of CFEL are promising.
\end{abstract}

Keywords: E-Learning, Customer Focused E-Learning, Private Training, Educommerce, Product Training, Corporate E-Learning

\section{Introduction}

Customer focused e-learning (CFEL) is customer training with computer-based technology. The idea of customer training is not new. But traditional classroom-learning does not meet all expectations of today's requirements. In contrast, e-learning is scalable and achievable from any location 24 hours a day. Training courses can be offered to a larger group of learners without raising the costs proportionally to the number of participants.

E-learning is becoming a differentiator. It gives business companies a new tool for marketing themselves to customers. The advantages of CFEL are in its mechanism of action. The awareness that CFEL positively affects all phases of the buying process establishes its deployment. Education is a factor to preserve and expand the customer base. As a differentiator it creates recognition and retains customers over time. The supposition behind CFEL is that "an educated customer is a loyal customer and a loyal customer is more likely to purchase products online" (Connell, 2001).

\section{Definitions}

\footnotetext{
Material published as part of these proceedings, either on-line or in print, is copyrighted by Informing Science. Permission to make digital or paper copy of part or all of these works for personal or classroom use is granted without fee provided that the copies are not made or distributed for profit or commercial advantage AND that copies 1) bear this notice in full and 2) give the full citation on the first page. It is permissible to abstract these works so long as credit is given. To copy in all other cases or to republish or to post on a server or to redistribute to lists requires specific permission from the publisher at Publisher@InformingScience.org
}

\section{E-Learning}

E-learning means learning through information and communication technology. This provides the learner the freedom of determining the learning process himself or herself (Back, Bendel, StollerSchai, 2001). Learner and teacher pool in order to 
build a virtual connection and to aid one another in the learning process.

The term e-learning is broad. Expressions like "computer-based training (CBT)", "web-based training (WBT)", "distance learning", etc. are aspects of e-learning (see Figure 1). But it is not always obvious where to set the boundaries. Bauer and Tillmann (2002) specify four conditions that have to be achieved simultaneously in electronic learning:

1. Utilization of modern multimedia technology

2. Offer of autonomous and interactive learning

3. Possibility of personal support

4. Utilization of electronical data and communication networks.

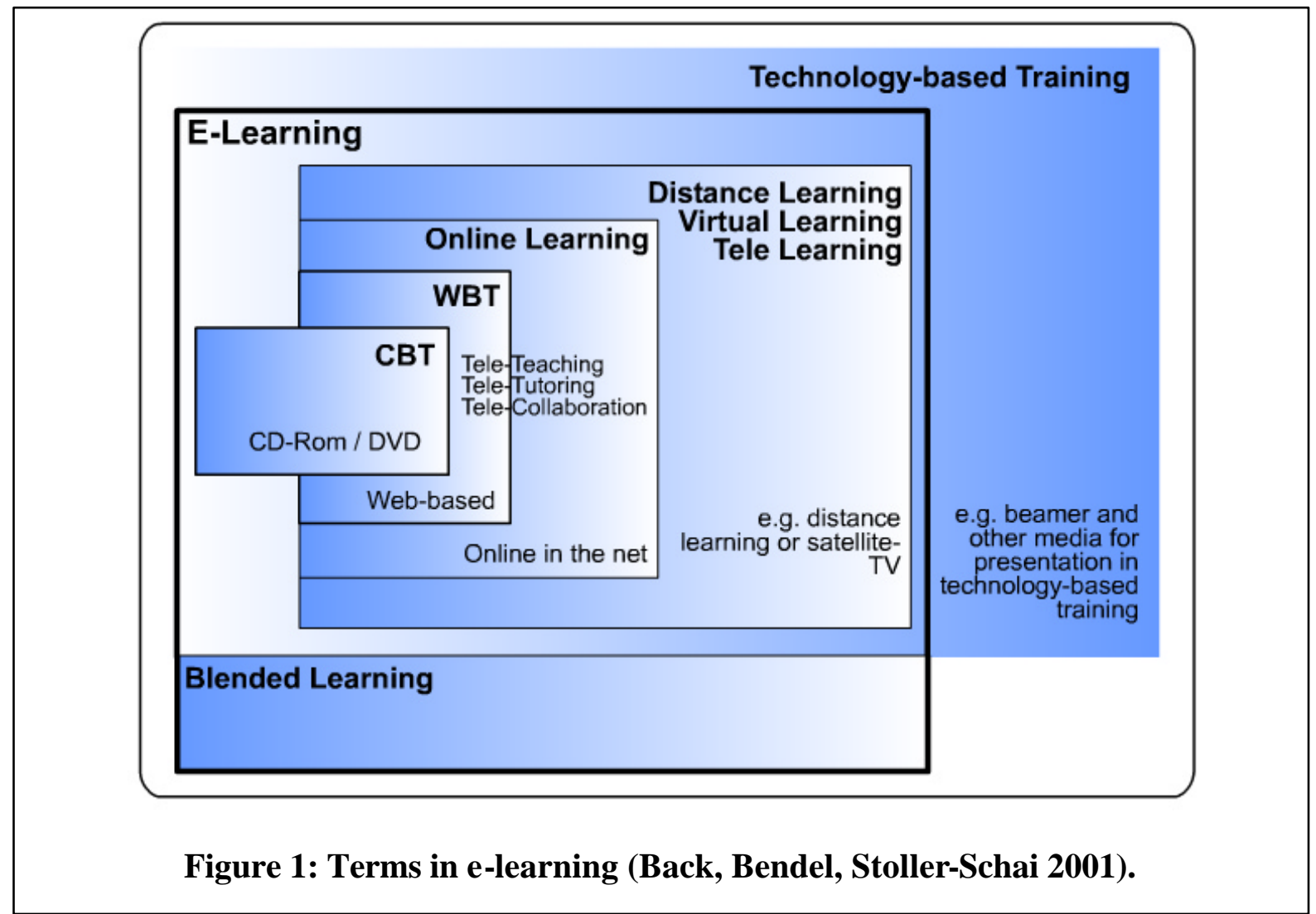

Technology-based training embraces learning with any learning and teaching material, therefore traditional technological instruments like beamer and television are involved as well.

Online learning denotes a form of e-learning where two or more computers are connected to a server via a network, for example the Internet. Learning programs through Internet or intranet are examples.

Blended learning is the combination of information and communication technology-based learning and instructor-led classes in the traditional classroom. According to estimations, providers should focus on blended learning since this strategy holds major potential because of the many-sides possibilities of application (Schmidkonz, 2002).

\section{Customer Focused E-Learning}

Customer Focused E-Learning (CFEL) is part of corporate e-learning. Employees, suppliers, partners, and customers are target groups of corporate e-learning (see Figure 2). 


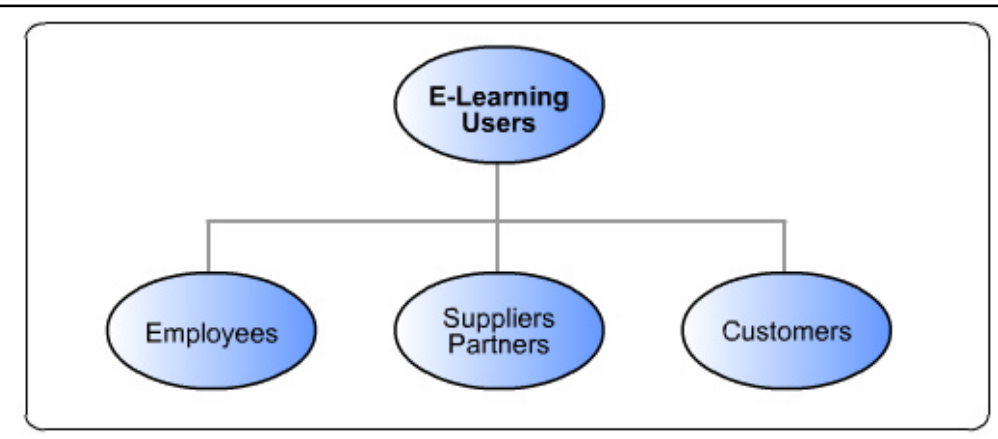

Figure 3: Target groups of corporate e-learning.
Sometimes two category groups within CFEL are distinguished: E-learning as a business segment (private training) and e-learning as a marketing instrument (educommerce) (see Fröde, Scheja, Weber, 2001). Additionally, product training can be seen as a third field of customer training. Because the products on the market permanently gain in complexity, sometimes electronic learning programs are provided with the products in form of an instruction manual. Customers have the possibility to familiarize themselves with the purchased product conveniently and at their own pace. This reduces the use of company hotlines. In the following the three strategies of customer focused e-learning, which are shown in Figure 3, are considered in detail.

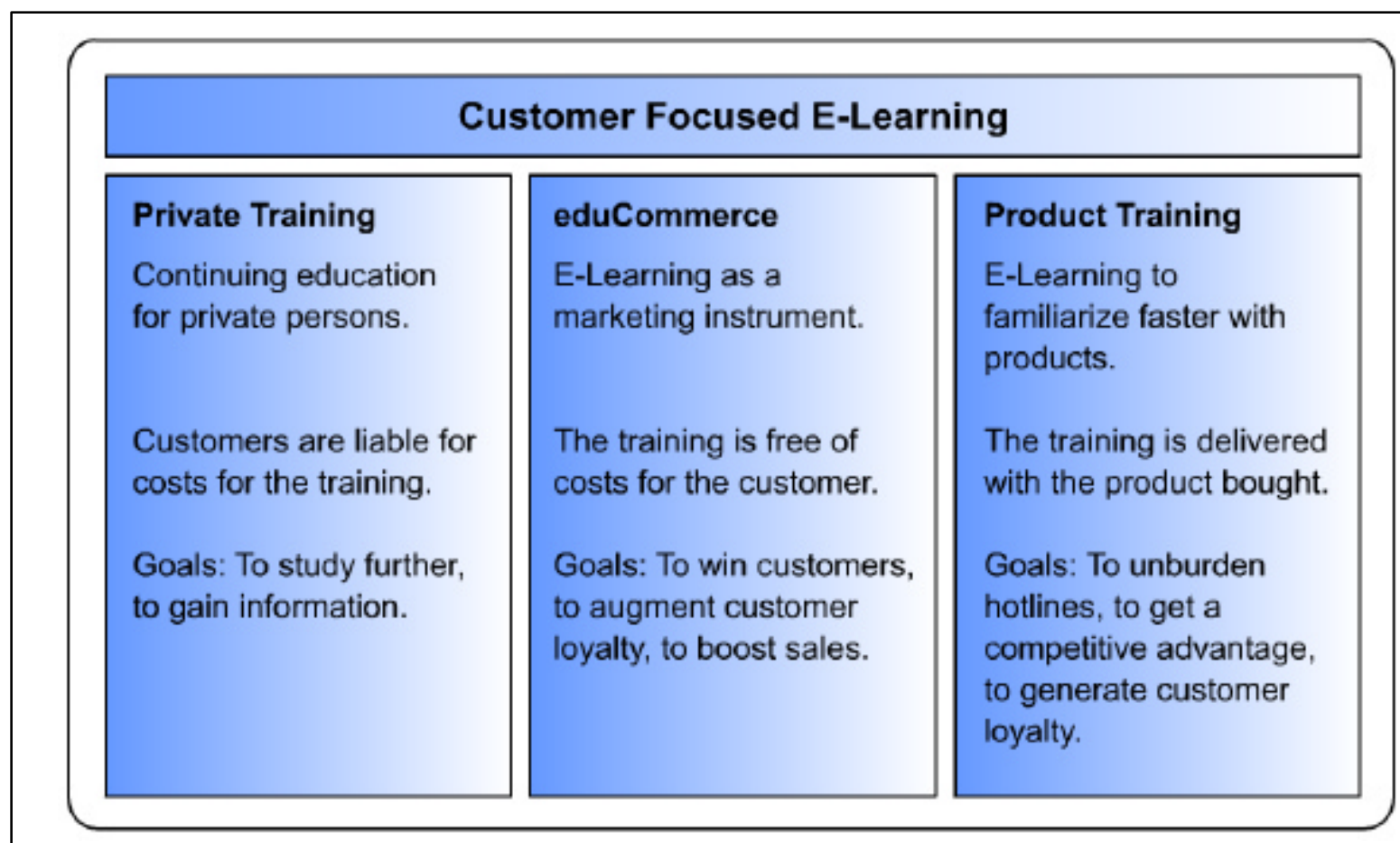

Figure 2: Strategies of customer focused e-learning.

\section{Types of Customer Focused E-Learning}

\section{Private Training}

Market researchers estimate that in Germany about 7 million people want to upgrade their skillset through studying on their own time. To gain personal and professional qualifications, individuals are willing to invest in continuing education (iBusiness, 2001). Some of the course participants want to improve career opportunities, income, and job guarantee through additional skills. Furthermore a lot of parents expect academic success of their children through e-learning programs. Some users just want to study further and to gain information on different subjects (cf. Fröde, Scheja, Weber, 2001). 
For a business company it is only a small step from employee training to customer training. This has attracted the companies' interest. Not only providers of traditional training but also e-learning providers are seizing the occasion and bringing standardized courses to the market.

In particular offers within the sector of private education have a big chance of success if they address target groups not being served adequately by providers of traditional training or not being served at all so far, e.g. learners in remote regions, people attached to a certain place, or disabled persons (Hasebrook, Rudolph, Steffens, 2002).

In the financial sector web-based training is widespread, because the financial sector is one of the most dynamic and knowledge-based branches of industry. Efiport (educational financial portal) of the Bankakademie Frankfurt (efiport, 2002) is an example offering a wide range of online courses, partly with international certification, to employees of the financial sector and to private investors (Hasebrook, Rudolph, Steffens, 2002).

There are numerous examples in the IT sector where whole training courses (e.g. system administrator, web designer, database developer) and other training courses for IT users (e.g. Microsoft Office training) are offered. For example Cisco provides more than 400 online and traditional courses with certification (Lischewsky, 2001a).

Dell will also open its internal training to the private sector in the future. The IBM Learning Services are another example where in Switzerland alone 30,000 people per year participate in training courses that are not free of charge. SAP has a wide range of e-learning solutions, as well. SAP makes about 11 percent of its revenue from training (Aldrich, 2000).

A very popular subject in the area of private education is learning software, e.g. on topics like foreign languages, mathematics, nature study, history etc. A lot of these courses are arranged for children. Such courses often are available on CD-ROM or they are web-based. The list of possible applications for such training is never-ending and so is the list of providers. More and more participants are enrolling in different courses because of the entertainment value or just for personal interest.

\section{Educommerce}

Educommerce, the process of using free online education to drive sales, is a mixture of marketing, learning, e-learning and e-commerce. The idea consists of positively affecting the purchase process and the customers' behaviour (positive conditioning) by the training offers (Connell, 2001). The providers offer learning courses for free, usually via the Internet, because they want to differentiate themselves from their competitors and get stronger customer loyalty (Whinston, Choi, 2001). E-learning is more than just continuing education; it becomes a marketing tool (M.I.T newmedia, 2001, Fröde, Scheja, Weber, 2001).

Employee training within an enterprise is often assigned to the human resources department as well as to the training centre, whereas educommerce usually belongs to the marketing department (M.I.T newmedia, 2001). A further difference to the employee training exists in the timeframe. While the training of employees represents a long-term process, educommerce relates to shorter time scale. The customer decides on the frequency and also on the duration of learning (M.I.T newmedia, 2001).

Compared to conventional marketing methods, educommerce is realized as intended marketing (permission marketing). So far, customers have been overwhelmed with banners and popup windows without asking for it. It is a proven fact that customers do not like to be pushed into a passive role of the recipient; they are annoyed by advertising. A negative conditioning might take place, i.e. the customer associates a product or a brand with a bad experience and refrains from purchasing further products of this brand. Offers of educommerce let the user choose whether he wants to participate in a course or not. Users appreciate the offer and regard it as added value (M.I.T newmedia, 2001). 
In order to point out the potential of educommerce, in the following the approach model of CFEL is considered in detail (cf. Figure 4) (see M.I.T newmedia, 2001).

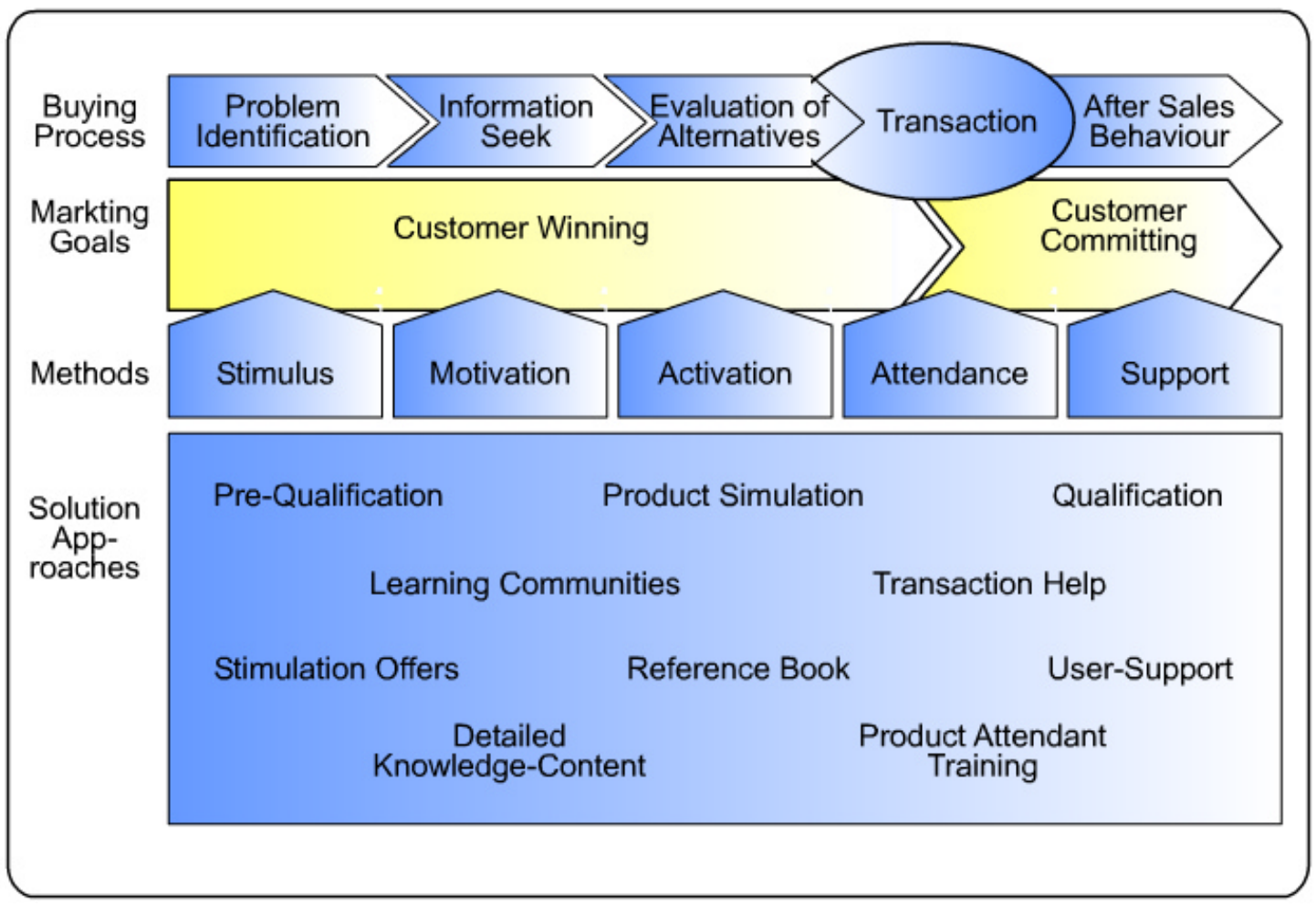

Figure 4: Approach model of CFEL (M.I.T newmedia, 2001).

The first line in Figure 4 represents the behavior of rational buyers. In the phase "problem identification" a problem or a need is perceived and the customer will respond. Then the buyer seeks relevant information and possible solutions. The found alternatives are evaluated and the buyer sets up an individual preference system. The transaction takes place, if a product or a service fulfills certain criteria of this preference system. To satisfy the buyer even after the purchase, further information, products, and services are needed.

Of course, in all phases of the buying process interferences can occur, which may lead the buyer to abort the process or to change the supplier. Educommerce can successfully contribute to each phase of the purchase process (cf. Figure 4) (Connell, 2001).

Already during the first phase "problem identification" educommerce is active. Pre-qualification and stimulation offers can wake customer needs. In the second phase "information search" educommerce supplies the buyer with information. The buyer is thus supported while searching for alternatives and solution proposals.

Educommerce contributes to diminishing fears and obstacles in relation to a product. Even product advantages can be presented more plausibly. The buyer can test the advantages of the product directly e.g. by a technical simulation and uncertainties about the product use are clarified. The duration of a sale process and the consulting time by salesmen can be shortened by e-learning, for example by video information (feedback AG, 2002b). Gartner Group estimates that in the year 2003 at least each tenth customer will test the product before purchasing or at least learns how to use it (Aldrich, 2000). The after sales support is considered under the aspect of "product training".

The number of the enterprises based on educommerce is rising. Besides US enterprises (IBM or Barnes\&Noble.com), more and more European enterprises are using educommerce, e.g. jobsintown.de. In 
health care educommerce is widely accepted. Not only consumers (patients) but also physicians and pharmacists are the target audience in the market for consumer goods. Since new medicines are often based on new knowledge, it is meaningful to train the medical personnel. For this purpose seven of the ten biggest US providers of medicines offer educommerce programs, e.g. Pfizer, AstraZeneca, Merck, and GlaxoSmithKline. At the suppliers of medical devices a similar picture is emerging. Eight of the ten largest suppliers, among them Johnson \& Johnson, Medtronic, Zimmer and Boston Scientific, use educommerce solutions (Hasebrook, Rudolph, Steffens, 2002).

Furthermore soft- and hardware suppliers have extensive experience with electronic learning offers. As examples the software businesses Computer Associates, People Soft, Microsoft, Clarify and SAP can be mentioned. Hardware providers deploying educommerce include Hewlett-Packard, Sun, Dell, EMC, and Cisco (Lischewski, 2001). Staffing and employment services use educommerce too. They procure knowledge mainly on how to apply and abilities that are in great demand, such as computer knowledge. The "Jobs University" of jobs.com and the career service of jobstown.de are examples (Lischewski, 2001). More and more, educommerce solutions are also used by publishing houses and booksellers such as Cook's Illustrated or Barnes\&Noble.com (Barron, 2000).

Eduventures.com provides an analysis of key players in the educommerce space (cf. Connell, 2001).

\section{Product Training}

Products and services become more and more complicated. A digital camera possesses far more than 50 functions and a homepage can easily contain 100 different features. The more complex a product or a service is, the more important it is to offer additional explanations to the buyers. The correct application of the purchased product from the beginning increases user satisfaction. A product or a trademark, which appears to be incomprehensible or unfriendly in handling, loses market share, especially outstanding technological products (e.g. IT range) and services.

Therefore product training courses gain in importance in the marketing process of products and services that need additional explanations. Product and process knowledge can be obtained in a demonstrative way by simulations. The knowledge does not remain theoretical, but can be deployed direct on examples. Possibilities, configurations, or product use can be taught on the basis of real scenarios (educommerce net, 2002).

After the purchase, the main interest is in the support of the customers with the goal of offering to the buyer an increase in value and of generating customer loyalty. Electronic instructions of use and communities are frequently used to differentiate them from the competitors and to offer the customer descriptive guidance and practical tips. Audiovisual descriptions are easier to understand than traditional complicated instructions for use in paper form (feedback AG, 2000a).

Product training courses are particularly suitable for vendors of complicated products, which launch a huge number of new developments every year. The SonyTrainNet (cf. Sony, 2002) is a good example. It offers Training courses for various Sony products. If Sony delivers a mixer, after the authorizing process the customer can log in to the SonyTrainNet and find training sessions on his or her equipment. At certain times a tutor is online answering the customers' que stions or the customers can chat with each other (De Monte-Robl, 2002).

Product training courses are often used to explain complicated and new services to the customers. Once more, the financial sector presents a lot of examples like the demo application of UBS, which explains the functionality of e-banking (cf. UBS, 2002).

Product training courses of soft- and hardware vendors are very popular. They deliver help programms and free training courses with their products. Probably the most famous example is Microsoft. In order to keep the sales figures high, they offer additional functions with every new release of the software. For 
the users it is not always easy to keep track. Therefore Microsoft offers different training courses e.g. for Windows 2000 and Windows Office. There is the office assistant (paper clip), a help pane, HTML assistance, assistance by questions and answers (Answer Wizard), warnings with auxiliary functions and tips (Alerts) and the possibility to download further information from the Internet. The user gets help whenever he needs it. Gartner Group estimates that such training courses cost software developers roughly 8 percent of total development costs (Aldrich, 2000).

Online communities, e.g. club Nokia (Nokia, 2002), are another form of product training. These offer users the possibility to exchange tips. The customers feel comfortable in the community and at the same time customer loyalty and product image is improved.

Training courses, which are available through online shopping, are other examples for product training. Screenshots are provided as small tutorials for helping with the registration process, the transaction, or security during the online shopping etc.

\section{Case Studies}

Within the framework of a diploma thesis three e-learning-providers in the Swiss market were interviewed on the recent situation of e-learning, the topic of customer focused e-learning, and on possible future trends in November 2002.

The purpose of presenting these case studies is to point out what Swiss providers know about CFEL, which experiences they have in CFEL, and where potentials and ranges of application of the different business models and instruments lie.

The names of the case study partners are not mentioned for privacy reasons. Table 1 reflects the business situation of the three selected providers. We selected enterprises with completely different basic cond $\mathrm{i}-$ tions. Provider A is a full service provider with selling offices in 170 countries, where e-learning is a seperate business field. Provider B is a small to medium-sized enterprise (SME) with its head office in Switzerland and 2 international selling offices. Provider $\mathrm{C}$ is a representative of the group of small enterprises operating only in the Swiss market.

\begin{tabular}{|l|l|l|l|}
\cline { 2 - 4 } \multicolumn{1}{c|}{} & \multicolumn{1}{|c|}{ Provider A } & \multicolumn{1}{c|}{ Provider B } & \multicolumn{1}{c|}{ Provider C } \\
\hline Region & Operates world-wide & $\begin{array}{l}\text { Head office in Switzer- } \\
\text { land, 2 international sell- } \\
\text { ing offices }\end{array}$ & $\begin{array}{l}\text { Operates only in the } \\
\text { Swiss market }\end{array}$ \\
\hline Employees & $\begin{array}{l}>3000 \text { employees in } \\
\text { Switzerland }\end{array}$ & $>20$ employees & employees \\
\hline $\begin{array}{l}\text { Business } \\
\text { Fields }\end{array}$ & $\begin{array}{l}\text { Besides the core bus i- } \\
\text { ness fields, the field } \\
\text { "learning services" is } \\
\text { divided into four divi- } \\
\text { sions that deal with e- } \\
\text { learning. }\end{array}$ & $\begin{array}{l}\text { Business fields } \\
\text { E-Business } \\
\text { E-Learning } \\
\text { E-Marketing }\end{array}$ & $\begin{array}{l}\text { Business fields } \\
\text { Education } \\
\text { E-Learning }\end{array}$ \\
\hline $\begin{array}{l}\text { Experience in } \\
\text { e-learning }\end{array}$ & 4 years. & 10 years & years \\
\hline
\end{tabular}

Table 1: Comparison of the case studys partners. 


\section{Provider A}

\section{E-learning at provider $\mathrm{A}$}

Provider A develops and carries out the training courses internally. A large number of the courses are IT product training, whereby the number of skills training courses offered is rising. The division respons ible for the training courses was generated from the internal continuing education. In the beginning the training courses were conducted only for internal staff. Today 80 percent of the participants are external.

Another division is responsible for large-scale e-learning projects. A third division implements the technical solutions and a fourth department carries out administrative tasks like course registrations or dispatching the training course documents.

The enterprise offers mainly end-to-end-solutions for the individual customer. That means that from the planning to the realization of a project everything is done. In particular large-scale enterprises and universities are customers of provider A.

\section{Customer focused e-learning at provider A}

At provider A the term CFEL is understood as a marketing instrument. Private training and product training are subsumed as well. The term "educommerce" is not well known.

Provider $\mathrm{A}$ is active in the areas private training and product training. In the area of educommerce no project has been realized so far in Switzerland, there were a few international projects done by this enterprise. In Switzerland educommerce is increasingly becoming an interesting subject, one customer is already interested in the conception and implementation of an educommerce solution.

Provider A estimates that in the Swiss e-learning-market only large providers with experience will be able to stand up to the competitors. Complete training strategies become more and more important. Technical questions, which often have been in the focus of e-learning projects until now, are displaced by questions concerning the learning culture and by didactical questions.

The provider wants to address SME in the future as well. A lower limit of 500 to 1000 co-workers was estimated. With less co-workers the development of individual solutions is not worthwhile since the costs exceed the possibilities of a smaller enterprise. Therefore provider A plans to establish a learning platform with standardized courses, where SMEs can participate depending upon their needs. Accounting will be based on a user-based system, i.e. payment per application.

Provider A considers it very difficult to succeed in the area of private education in Switzerland. A decrease of registrations of private persons has already been experienced. But direct selling of standardized continuing education to enterprises could be an opportunity for the Swiss market. Provider A estimates that educommerce provides quite a lot of potential, especially if employee training and customer training can be combined, but only if the training course is accommodated to the target group can an added value be generated for the customer.

\section{Provider B}

\section{E-learning at provider B}

The enterprise offers customized teaching programs. In particular large enterprises belong to B's customers. For SME the expenses for e- learning solutions are often too high. The solutions developed by provider B serve for employee training. In addition applications are developed for training of distributors and customers. 
The enterprise already has 10 years experience in e-learning. The production of multilingual e-learning solutions is provider B's core competence. This capability is highly required in Switzerland because it is a multilingual country.

\section{Customer focused e-learning at provider B}

Provider B interprets CFEL as e-learning for the training of customers. Indirect and direct CFEL are distinguished. By indirect CFEL distributors and salesmen are trained, direct CFEL however contacts the customers directly. The term educommerce is also not well known, however, some projects in this range have already been accomplished. Provider B has also gained some experience in the field of product training while $\mathrm{B}$ is not active in private training.

Provider B estimates that within the area of private continuing education only standardized solutions will become generally accepted. For the production of individual teaching programs the Swiss market is not broad enough.

Educommerce represents large potential according to provider B. There are a lot of projects where elearning is deployed as a marketing instrument. Educommerce solutions offer a good possibility of generating a genuine increase in value.

According to statements of provider B especially training courses for complex products will become generally accepted. The enterprise has experienced that above all, product training courses on the Internet increase efficiency and relieve hotlines. However, the competitors should not gain too much information on the presented products through such training courses.

\section{Provider C}

\section{E-learning at provider $\mathbf{C}$}

Provider $\mathrm{C}$ offers different standardized products like training as a call center agent. Private persons as well as coworkers of enterprises attend the offered training courses. Not only standardized solutions but also applications customized to the specification of large enterprises are realized. Provider $\mathrm{C}$ accomplishes everything from the planning of e-learning content to the hosting of systems.

\section{Customer focused e-learning at provider C}

Provider C associates CFEL with e-learning applications in accordance with the customers' needs. Some projects on private continuing education have already been realized, but the enterprise has never been active in educommerce and product training areas. The term educommerce is not well known either.

Company $\mathrm{C}$ estimates that the Swiss market is too small in order to achieve general acceptance. This kind of advertisement is not worthwhile for most of the enterprises since free training courses cannot generate enough sales volume. However, provider $\mathrm{C}$ grants good chances to the product training courses. Particularly for products which are internationally sold, the production of product training courses is worthwhile primarilyin order to relieve helpdesks.

\section{Conclusion}

This paper reports on applications of customer focused e-learning. Three case studies of e-learningproviders in the Swiss market are presented in order to provide an insight into possible applications of the different business models of CFEL. 
The three providers presume CFEL will become a new and widely accepted segment within e- learning. According to the statements of the three case study-partners, in private education it will be very hard for providers in Switzerland to compete because the potential of the multilingual Swiss market is not large enough. International companies, which offer solutions for a much broader market are expected to have a better chance of success.

Table 2 recapitulates the activities in CFEL of the interviewed providers.

\begin{tabular}{|l|l|l|l|}
\cline { 2 - 4 } \multicolumn{1}{c|}{} & \multicolumn{1}{c|}{ Provider A } & \multicolumn{1}{c|}{ Provider B } & \multicolumn{1}{c|}{ Provider C } \\
\hline Private Training & Projects realized. & No projects. & Projects realized. \\
\hline Educommerce & $\begin{array}{l}\text { International projects, } \\
\text { but no project in Swit- } \\
\text { zerland so far. }\end{array}$ & No projects. & No projects. \\
\hline Product Training & Projects realized. & Projects realized. & No projects. \\
\hline
\end{tabular}

Table 2: CFEL activities of interviewed providers.

\section{References}

Aldrich, C. (2000). Customer-Focused E-Learning: The Drivers from http://www.learningcircuits.org/jul2000/aldrich.html [accessed 2002-05-29].

Back, A., Bendel, O., Stoller-Schai, D. (2001). E-Learning im Unternehmen, Zürich: Orell Füssli Verlag AG 2001.

Bauer, R., Tillmann, P. (2001). Einstieg ins E-Learning, Nürnberg: BW Bildung und Wissen Verlag und Software GmbH 2001.

Conell (2001). EduCommerce: Online Learning Migrates to the E-Commerce Arena from http://www.eduventures.com/pdf/eduCommerce.pdf [accessed 2002-09-30].

De Monte-Robel, I. (2002). Nachhilfe im virtuellen Klassenzimmer, in: HANDELSBLATT, 15.2.2002.from http://194.7.100.66/tn pages/press/handelsblatt-150202.htm [accessed 2002-07-18].

eduCommerce net (2002). eduCommerce Technologien from http://www.markatweb.de/educommercenet/Deutsch/educommerce technologien.htm [accessed 2002-05-21].

efiport (2002). Unternehmen from http://www.efiport.de/efiport/unternehmen/ [accessed 2002-01-10].

feedback AG (2002a). Solution - Kunden - Gebrauchsanweisung from http://www.feedback.de/streaming/s solutions kunden.php3? content=content/assistent/in index\&id=109 [accessed 2001-09-16].

feedback AG (2002b). Solution - Kunden - Produtkinformation from http://www.feedback.de/streaming/s solutions kunden.php3?content=content/assistent/ index\&id=108 [accessed 2001-09-16].

Fröde, F., Scheja, M., Weber, G. (2001). eLearning - eine neue Art zu Lernen, ein neuer Markt from http://www.informatik.htw-dresden.de/ htw10935/papers/Onlinemarketing eLearning.pdf [accessed 2002-08-07].

Hasebrook, J., Rudolph, D., Steffens, U. (2002). E-Learning Business Opportunities \& Strategies, Chesterfield: Datacomm Research Company 2002.

IBusiness (2002). Kundenbindung durch E-Learning from http://www.ibusiness.de/members/cbt/db/cbt.959000851ln.2946hr.html [accessed 2002-09-15].

Lischewski, H. (2001). Kunden bilden und behalten, in: Diebold Management Report 30 (2001) 3, S. 26-29. From http://www.competence-site.de/elearning.nsf/2FBAC7D1389F5A63C1256BA0002D3091/\$File/dmr 0301 elearning.pdf [accessed 2002-12-02]. 
M.I.T newmedia (2001). eduCommerce: Schulung als Marketingmassnahme from http://www.educommerce.mit.de/whitepaper/educommerce Wpmit.pdf [accessed 2002-05-21].

Nokia (2002). Club Nokia fro $m$ http://www.club.nokia.com/ [accessed 2002-12-02].

Schmidkonz, C. (2002). Erfolgsfaktoren für E-Learning from http://www.contentmanager.de/magazin/artikel 139-print erfolgsfaktoren e learning.html [accessed 2002-14-10].

Sony (2002). Sony TrainNet from http://194.7.100.66/index.asp [accessed 2002-12-02].

UBS AG (2002). UBS e-banking via Internet from http://www.ubs.ch/e/ebanking/classic/demo.html [accessed 2002-12-01]

Whinston, A., Choi, S-Y. (2001). Educommerce: E-Learning as a Marketing Tool from http://business.cisco.com/prod/tree.taf\%3Fasset $\mathrm{id}=67649 \mathrm{\& public}$ view=true\&kbns=1.html [accessed 2002-05-09].

\section{Biography}

Corinne Montandon is a research and teaching assistant (Ph.D. student) at the Institute of Information Systems at the University of Bern. She has a licenciate in Business Administration from University of Bern (lic.rer.pol.). Her research areas are e- learning and the development and implementation of standards and tools for electronic learning. Currently, Corinne is project manager of the Swiss Virtual Campus Project OPESS (Operations Research, ERP- and SCM-Systems). This project aims to achieve an integrated approach to Web-based teaching in the field of Production Management. More information can be found at http://opess.ie.iwi.unibe.ch/

Marianne Zentriegen has a licenciate in Business Administration from University of Bern (lic.rer.pol.). She wrote her diploma thesis on the topic of customer focused e-learning. Her research interests include electronic commerce, e- learning, and marketing. 